\title{
GABA Inhibits Migration of Luteinizing Hormone-Releasing Hormone Neurons in Embryonic Olfactory Explants
}

\author{
Susan M. Fueshko, Sharon Key, and Susan Wray \\ Laboratory of Neurochemistry, National Institute of Neurological Diseases and Stroke, National Institutes of Health, \\ Bethesda, Maryland 20892-4130
}

\begin{abstract}
During development, a subpopulation of olfactory neurons transiently expresses GABA. The spatiotemporal pattern of GABAergic expression coincides with migration of luteinizing hormone-releasing hormone (LHRH) neurons from the olfactory pit to the CNS. In this investigation, we evaluated the role of GABAergic input on LHRH neuronal migration using olfactory explants, previously shown to exhibit outgrowth of olfactory axons, migration of $\mathrm{LHRH}$ neurons in association with a subset of these axons, and the presence of the olfactory-derived GABAergic neuronal population. $\mathrm{GABA}_{\mathrm{A}}$ receptor antagonists bicuculline $\left(10^{-5} \mathrm{M}\right)$ or picrotoxin $\left(10^{-4} \mathrm{M}\right)$ had no effect on the length of peripherin-immunoreactive olfactory fibers or $\mathrm{LHRH}$ cell number. However, LHRH cell migration, as determined by
\end{abstract}

Developmentally, the olfactory placode gives rise to a variety of cell types, including four different neuronal phenotypes: olfactory receptor neurons (ORNs) (for review, see Farbman, 1994), pheromone receptor neurons (PRNs) (for review, see Halpern, 1987), luteinizing hormone-releasing hormone (LHRH) neurons (Schwanzel-Fukuda and Pfaff, 1989; Wray et al., 1989a,b), and GABAergic neurons (Tobet et al., 1996; Wray et al., 1996). Maintained within the nasal epithelium, ORNs and PRNs establish an intricate arrangement of olfactory-derived axons forming separate nerves (olfactory and vomeronasal and nervus terminalis), all navigating a similar course through the nasal septum but targeting distinct locations within the CNS (for review, see Halpern, 1987; Farbman, 1994). In contrast to the sensory neurons, LHRH neurons exit the nasal cavity and migrate across the nasal septum, through the cribiform plate, and into the brain. The timing of the approach of LHRH cells to the nasal forebrain junction may be critical, with alterations that prevent CNS entrance resulting in severe reproductive dysfunction, as evidenced in Kallmann's syndrome (Rugarli et al., 1993; Quinton et al., 1997). It is hypothesized that LHRH neurons move into the brain along a subset of peripherin-immunoreactive, olfactory axons (Wray et al., 1994), the outgrowth of which precedes the cellular migration. Although a preferential association exists between LHRH neurons and peripherin axons, the migratory guidance mechanisms are unknown.

During development, GABA responses have been implicated in neuronal differentiation, neurite outgrowth, growth cone mo-

\footnotetext{
Received Aug. 28, 1997; revised Jan. 14, 1998; accepted Jan. 19, 1998.

We are grateful to Dr. William Hayes and Dr. Evelyn Ralston for their helpful discussions and critical reading of this manuscript.

Correspondence should be addressed to Dr. S. Wray, Laboratory of Neurochemistry, National Institutes of Health, Building 36, Room 4D-12, Bethesda, MD 20892. Copyright (C) 1998 Society for Neuroscience $0270-6474 / 98 / 182560-10 \$ 05.00 / 0$
}

the distance immunopositive cells migrated from olfactory pits, was significantly increased by these perturbations. Addition of tetrodotoxin $\left(10^{-6} \mathrm{M}\right)$, to inhibit $\mathrm{Na}^{+}$-transduced electrical activity, also significantly enhanced LHRH migration. The most robust effect observed was dramatic inhibition of LHRH cell migration in explants cultured in the presence of the $\mathrm{GABA}_{\mathrm{A}}$ receptor agonist muscimol $\left(10^{-4} \mathrm{M}\right)$. This study demonstrates that GABAergic activity in nasal regions can have profound effects on migration of LHRH neurons and suggests that GABA participates in appropriate timing of $\mathrm{LHRH}$ neuronal migration into the developing brain.

Key words: GABA; GnRH; olfactory; peripherin; tetrodotoxin; immunocytochemistry

tility, and cellular migration (Lauder, 1987; Cherubini et al., 1991; Meier et al., 1991; Baher et al., 1994). In contrast to its well characterized, hyperpolarizing, and inhibitory role in mature neurons, evidence indicates that the developmental capacity of GABA arises from depolarizing, excitatory actions (Obata et al., 1978; Meier et al., 1985; Cherubini et al., 1991). Examination of membrane properties of LHRH neurons in embryonic olfactory explants showed that shortly after emigrating from the olfactory pit, in addition to displaying a variety of ion channels characteristic of mature neurons, these cells exhibited spontaneous activity and functional, depolarizing $\mathrm{GABA}_{\mathrm{A}}$ receptors (Kusano et al., 1995). Interestingly, the spatiotemporal expression of glutamic acid decarboxylase (GAD) mRNA in the olfactory pit region coincides with migration of LHRH neurons from the olfactory pits (Wray et al., 1996). GAD mRNA expression, as well as GAD and GABA immunoreactivity, is restricted to a discrete developmental window from embryonic day 11.5 (E11.5) to E16.5, peaking at E12.5 (Wray et al., 1996). At E12.5, a boundary of immunoreactive axons is clearly detected in the area of the nasalforebrain junction, bordering the cribiform plate. These findings raise the possibility that GABA plays a role in the development of the LHRH cell population.

In this study, we examined the effect of GABA on LHRH migration using an embryonic olfactory explant system. This in vitro model has proven to be an ideal system for studying directional axonal outgrowth, neurophilic migration of LHRH neurons in association with a subset of these axons (Fueshko and Wray, 1994), and the role of the olfactory-derived GABAergic neuronal population (Kusano et al., 1995; Wray et al., 1996). The present findings demonstrate that GABAergic activity decreases the distance that LHRH neurons migrate. This, in turn, points to a novel mechanism in which GABA acts as an embryonic signal, regulating $\mathrm{LHRH}$ cell entrance into the CNS. 

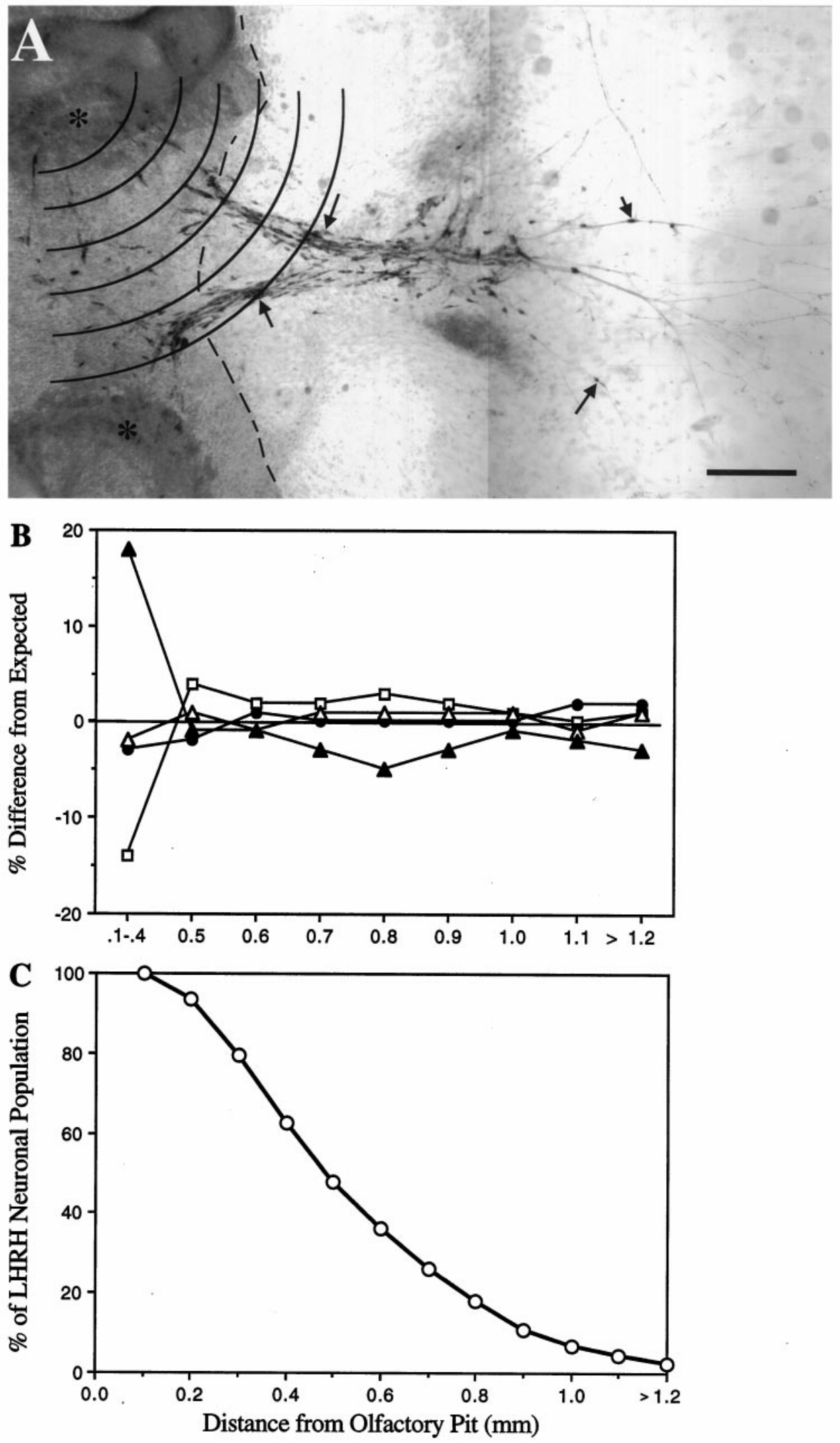

Figure 1. Spatiotemporal migration of LHRH neurons in olfactory explants occurs in the absence of serum factors. $A$, Olfactory explant maintained in SFM for $7 \mathrm{~d}$ and immunocytochemically stained for LHRH. Numerous LHRH neuropeptideexpressing cells were observed in $>90 \%$ of the explants cultured in SFM. Bilateral, directional tracks of LHRH neurons (arrows; similar to those observed in vivo) emerged from olfactory pits (asterisks) and migrated onto substratum-producing cells surrounding the explant. The dashed line indicates the boundary between main tissue mass and non-neuronal carpet of cells. Concentric arcs, $0.1 \mathrm{~mm}$ apart, represent zones used to determine the distance that olfactory axons and LHRH cells migrated from the olfactory pits; placement of the center circle was over the olfactory pit. Scale bar, $200 \mu \mathrm{m}$. $B$, Interassay variability in LHRH cell migration was compared for SFM cultures generated on different culture dates. The percent difference of each culture date (open squares and triangles, filled circles and triangles) from expected values (generated from all cultures grown in SFM) is shown. Note that at all distances beyond the main tissue mass $(>0.4 \mathrm{~mm})$, there is $<5 \%$ difference from the expected population; i.e., the location of LHRH neurons was independent of culture date. $C$, To determine the migrational history of LHRH neurons before treatment, all cultures grown in SFM were grouped $(n=$ 77), and the distribution of the LHRH neuronal population $(n=7813)$ was plotted as the distance cells migrated from the olfactory pit (migratory zones). Approximately $50 \%$ of the LHRH neuronal population migrates off of the main tissue mass (beyond zone 4).

\section{MATERIALS AND METHODS}

Olfactory explants. Olfactory explants were prepared as described previously (Fueshko and Wray, 1994). Briefly, E11.5 mouse embryos were obtained from timed pregnant NIH Swiss females according to National
Institutes of Health guidelines. The olfactory epithelium was removed and plated on glass coverslips $(12 \times 24 \mathrm{~mm}$; Gold Seal $)$ coated with $10 \mu \mathrm{l}$ of chicken plasma (Cocalico, Philadelphia, PA). Thrombin (10 $\mu$ l; Sigma, St. Louis, MO) was then added to adhere (thrombin and plasma clot) the 
Figure 2
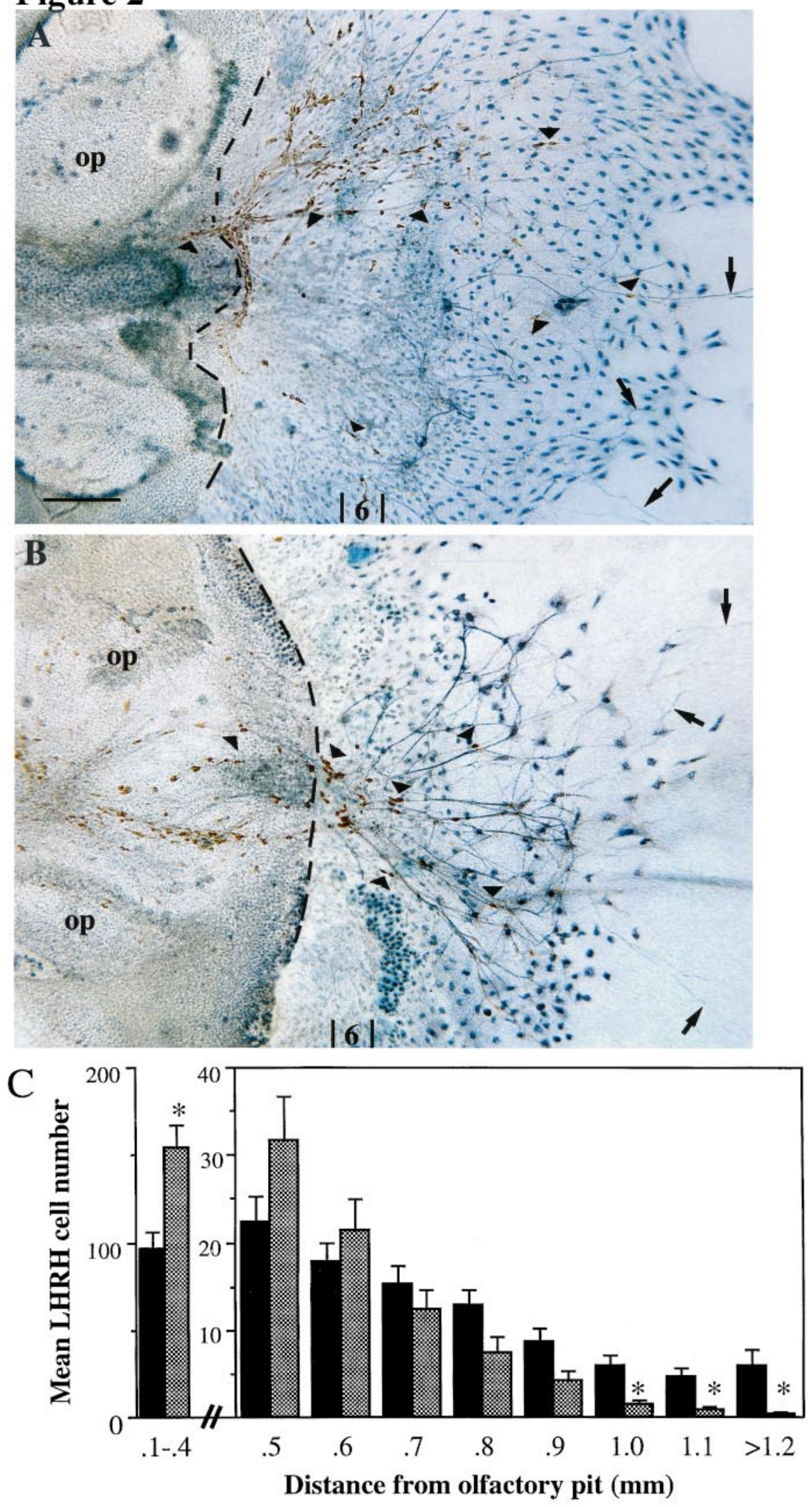

Figure 5
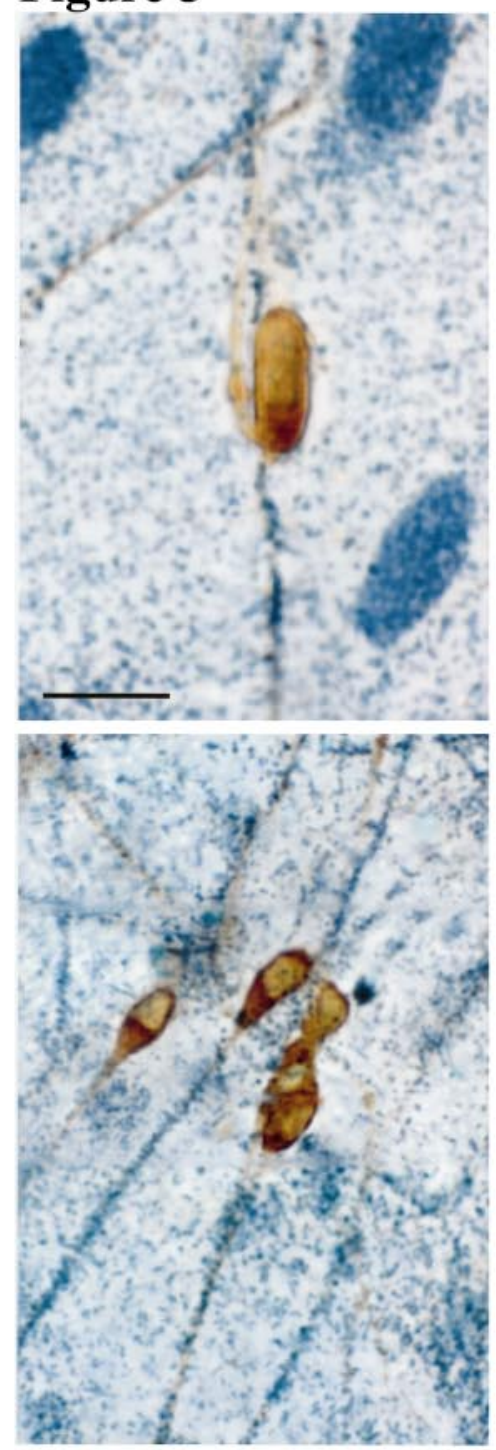

Figure 2. Left. Migration of LHRH neurons was altered by changes in GABAergic activity. Photomicrographs of olfactory explants maintained in the presence of bicuculline $\left(10^{-6} \mathrm{M} ; A\right)$ or muscimol $\left(10^{-4} \mathrm{M} ; B\right)$ for $7 \mathrm{~d}$ and then immunocytochemically stained for LHRH and peripherin. Under all treatment conditions, peripherin fibers (arrows) extended to the edge of the culture, and LHRH neurons (brown cells, arrowheads) migrated away from the olfactory pits $(o p)$. However, more LHRH neurons appeared farther from the olfactory pits when cultured in the (Figure legend continues) 
explant to the coverslip. To eliminate unknown serum constituents, as well as the possibility that effects of pharmacological agents on LHRH cell movement would be masked under serum-containing conditions, olfactory explants were maintained in a defined serum-free medium (SFM) (Wray et al., 1991) for $7 \mathrm{~d}$ at $37^{\circ} \mathrm{C}$ in a humidified atmosphere with $5 \% \mathrm{CO}_{2}$. The media were changed twice a week, and one dose of fluorodeoxyuridine $\left(8 \times 10^{-5} \mathrm{M}\right.$, Sigma) was given at day 3 for $3 \mathrm{~d}$. This treatment was found to be effective in decreasing the number of nonneuronal cells without affecting either the general health of the explant or LHRH cell number.

To ensure that the spatiotemporal appearance of LHRH neurons was maintained in SFM, we examined LHRH cell number and directionality of cell emergence from the olfactory pit, as well as LHRH association with, and migration along, peripherin-positive olfactory axons. Directional movement of large numbers of LHRH cells was observed (see Fig. $1 A$ ), as was association of LHRH neurons with peripherin axons. No differences were detected between cultures maintained in SFM and serum-containing medium. Thus, phenotypic expression of LHRH neuropeptide, LHRH cell survival, and directional LHRH migration were maintained in the absence of serum factors.

Explants in experimental groups were maintained in SFM containing reagents (obtained from Sigma) that (1) block $\mathrm{GABA}_{\mathrm{A}}$ receptors [bicuculline (bicuculline methochloride, $\left.10^{-5} \mathrm{M}\right)$ and picrotoxin $\left(10^{-4} \mathrm{M}\right)$ ], or (2) activate $\mathrm{GABA}_{\mathrm{A}}$ receptors [muscimol $\left(10^{-4} \mathrm{M}\right)$ ]. In addition, tetrodotoxin (TTX, $10^{-6} \mathrm{M}$ ) was used as a general inhibitor of all electrical activity (Catterall, 1980; Hille, 1984), including that generated via GABAergic input. Drug concentrations were based on effectiveness in previous electrophysiological studies (Kusano et al., 1995). Chronic treatments were initiated at $1 \mathrm{~d}$ in vitro (div), before the emergence of $\mathrm{LHRH}$ cells from the olfactory pits, and replenished at 3 and 6 div. Control cultures were maintained in SFM that was changed, as in the treatment groups, at 1, 3, and 6 div. After 7 div, cultures were processed for singleand double-label immunocytochemistry.

Immunocytochemistry. A polyclonal antibody against pro-LHRH (SW-1, 1:2500; Wray et al., 1988) was used to detect LHRH. Antiperipherin 199 (1:1600) was obtained from Dr. R. Goldman (Parysek and Goldman, 1988). Single-label immunocytochemistry was performed as described previously (Wray et al., 1989a). Briefly, cultures were fixed (4\% formaldehyde), rinsed in PBS, and blocked by incubating in $10 \%$ normal goat serum (NGS) and $0.3 \%$ Triton X-100. After two PBS washes, cultures were incubated in primary antiserum overnight at $4^{\circ} \mathrm{C}$; negative controls were incubated in $10 \%$ NGS without primary antibody. On day 2 , cultures were rinsed and incubated in biotinylated secondary antibody (1:500; Vector Laboratories, Burlingame, CA), followed by avidinbiotin-conjugated horseradish peroxidase complex (1:600, Vectastain Elite ABC-peroxidase; Vector). Staining was visualized using 3',3diaminobenzidine (DAB, Sigma) and glucose oxidase. Cultures were counterstained with $0.05 \%$ methyl green, dehydrated, cleared with xylene, and mounted in Permount (Fisher Scientific, Pittsburgh, PA).

To examine the distribution of two substances within a single culture, explants were processed sequentially using two different antibodies and chromogens. After visualization of the first antigen-antibody complex with DAB (see section above), the cultures were blocked (30 min, normal rabbit serum), rinsed, fixed (15-20 min, 4\% formaldehyde), transferred to the second primary antibody, and incubated overnight at $4{ }^{\circ} \mathrm{C}$. Visualization of the second antigen-antibody complex was performed using benzidine dihydrochloride (BDHC, Sigma) (Wray et al., 1988). Briefly, after incubation in $\mathrm{ABC}$-peroxidase, cultures were rinsed and placed (2 $\mathrm{min})$ in $0.5 \%$ gluteraldehyde in sodium cacodylate buffer $(0.1 \mathrm{M}, \mathrm{pH} 6.5)$. After a $10 \mathrm{~min}$ rinse in this same buffer, the explants were placed in a BDHC solution ( $100 \mathrm{mg}$ of BDHC, $77.5 \mathrm{ml}$ of distilled $\mathrm{H}_{2} \mathrm{O}$, and $22.5 \mathrm{ml}$ of $100 \% \mathrm{EtOH}$, to which were added $1 \mathrm{ml}$ of $0.32 \mathrm{M}$ sodium nitroprusside and $12 \mathrm{ml}$ of $0.2 \mathrm{M}$ sodium cacodylate buffer). The final reaction was visualized with $60 \mu \mathrm{l}$ of $10 \% \mathrm{H}_{2} \mathrm{O}_{2}(5-10 \mathrm{~min})$. Controls for double-label experiments were done as reported previously (Wray et al., 1988). All cultures were counterstained and mounted as described above.

Quantitation of fiber outgrowth and cell migration. Quantitation of these two parameters was performed on a light microscope, using an eyepiece reticule etched with a series of concentric circles separated by a uniform distance of $0.1 \mathrm{~mm}$ (see Fig. $1 A$ ). Because no specific marker exists for the axonal subpopulation on which LHRH neurons migrate, overall olfactory axonal outgrowth was monitored using the intermediate neurofilament peripherin. For fiber measurements, the center of the circles was placed over each olfactory pit, and the outermost zone containing a peripherin fiber network was recorded; this method was chosen because of the complex nature of the fiber network that prevented the quantitation of individual fibers as well as the measurement of individual fibers. The number of cultures with fibers in a given zone was plotted as a percent of cultures analyzed versus the distance from the olfactory pit. For diagrammatic purposes, the total distance examined $(2.7 \mathrm{~mm})$ was divided into $0.3 \mathrm{~mm}$ segments, and frequency histograms were generated. For cell migration measurements, placement of the circles was similar, but the total number of cells in each zone was recorded, allowing LHRH neuronal populations to be compared between treatment groups (see below). The interassay variability was evaluated by examining $\mathrm{LHRH}$ cell distributions obtained from cultures grown in SFM but generated on separate culture dates (see Fig. $1 B$ ). In these four culture groups, the variation of LHRH cell distributions from an expected population distribution (obtained from contingency tables; see Statistical analysis) was $<5 \%$ beyond zone $4(>0.4 \mathrm{~mm}$ from the olfactory pit). A greater variation (up to $18 \%$ ) was observed in zones $1-4$, which primarily can be attributed to the difficulty in counting large numbers of cells clustered together on the thicker tissue mass.

Statistical analysis. A mean total LHRH cell number was obtained for each treatment group and analyzed using a one-way ANOVA. These values were taken as an indication of LHRH cell survival. Data for overall fiber outgrowth, as well as movement of LHRH neurons, were compared for SFM and experimental groups by constructing contingency tables and applying the $\chi^{2}$ test for independence. Such an analysis determines whether the observed sample differences signify real differences among populations or whether they are differences that one might expect among samples from the same population. This nonparametric analysis was chosen because zonal distance $(0.1 \mathrm{~mm}$ grouping) was used instead of continuous measurements, and the number of observations per treatment (culture number) was not identical. Thus, by this analysis, the expected values for the number of observations for every group were calculated, based on the hypothesis of independence, and the expected values were compared with the observed values (Agresti, 1984). A stringent $p$ value, of 0.001 , was chosen for significance in these experiments. For graphing, the observed value for each group was divided by its expected value and multiplied by 100 , and the difference between either experimental and calculated (see Fig. $1 B$ ) or treated and SFM (see Fig. 3 ) was plotted for each zone. (Note: Using this method, if the groups being compared behaved similarly in a given zone, the plotted value would equal zero.) If the $\chi^{2}$ analyses indicated significant differences, a one-way ANOVA was used to evaluate the number of LHRH cells located within discrete migrational zones.

\section{RESULTS}

The fact that GABAergic neurons (1) are present in the olfactory pit in a discrete time window during the LHRH migratory period (Tobet et al., 1996; Wray et al., 1996), (2) extend GABAergic axons to the base of the cribiform plate (Wray et al., 1996) and (3) cause

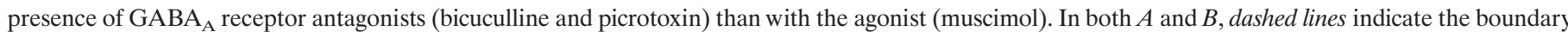

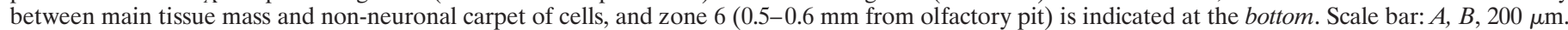

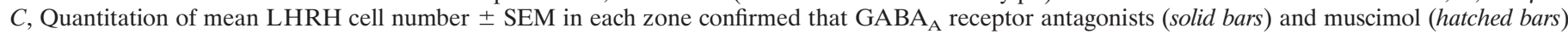

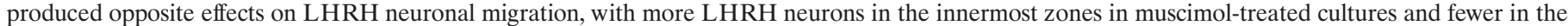
outer zones compared with cultures treated with antagonists (asterisks indicate values that are significantly different by ANOVA; $p \leq 0.02$ ).

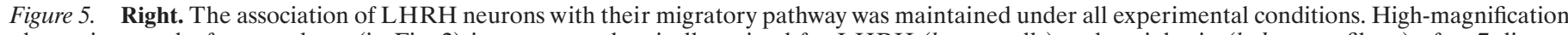

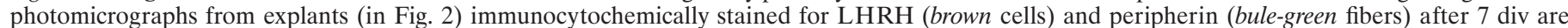

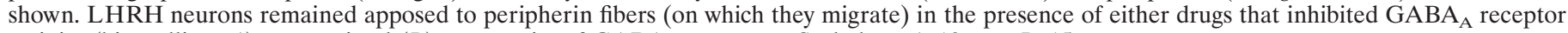

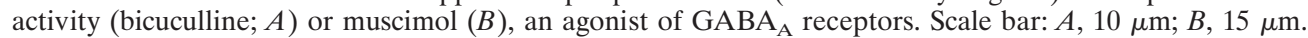


depolarization of LHRH neurons, in vitro, via functional $\mathrm{GABA}_{\mathrm{A}}$ receptors (Kusano et al., 1995), makes GABA a strong candidate for modulating LHRH neuronal migration through nasal regions.

To determine the role GABA plays in orchestrating olfactory and LHRH system development, olfactory explant cultures were treated with $\mathrm{GABA}_{\mathrm{A}}$ receptor antagonists picrotoxin and bicuculline or with the receptor agonist muscimol. After $7 \mathrm{div}$, explants were fixed and immunocytochemically processed, and four parameters were assayed: migration of LHRH neurons, LHRH cell survival, association of LHRH cells with peripherin fibers, and peripherin fiber outgrowth.

\section{Manipulation of $\mathrm{GABA}_{\mathrm{A}}$ receptors dramatically alters LHRH cell distribution}

We have shown previously (Fueshko and Wray, 1994) that the migrational pattern of LHRH neurons reproducibly occurs in vitro, with a shift in location of the LHRH cell population from the olfactory pit to the edge of the main tissue mass occurring from 1 to 3 div and continuing to more distant sites in the periphery of the culture from 3 to 5 div. The migrational history of the LHRH cell population in SFM cultures $(n=77)$ is shown in Figure $1 C$. After 7 div, under normal culture conditions, $48 \%$ of LHRH neuronal population migrated beyond zone $4(>0.4$ $\mathrm{mm}$ from the olfactory pit), which is often the edge of the main tissue mass (see Figs. 1, 2, 6, dashed lines), 37\% of the population migrated $0.5-0.8 \mathrm{~mm}$ from the olfactory pit, and the remaining $11 \%$ migrated $>0.8 \mathrm{~mm}$ away from the olfactory pit [equivalent to the distance traveled by LHRH neurons in vivo during the same embryonic time window (between 0.82 and $0.92 \mathrm{~mm}$ )].

Under all four treatment conditions, LHRH neurons were observed at the outermost edge of culture. However, a shift in the location of LHRH neurons was noted for cultures treated with muscimol (Fig. 2, compare $A, B$ ). $\chi^{2}$ analysis revealed significant differences among treatment groups, in the distance traversed by the entire LHRH population $\left(\chi^{2}=875.5 ; p<0.001\right.$; SFM, $n=$ 77; muscimol, $n=47$; bicuculline, $n=68$; picrotoxin, $n=49$ ). Post hoc tests comparing each of the four treatment groups revealed no significant differences between the location of LHRH neurons in cultures treated with bicuculline versus picrotoxin $\left(\chi^{2}\right.$ $=21.1 ; p \geq 0.001)$ and thus these two groups were combined (antagonists, $n=117$ ). The mean number of LHRH neurons in each zone in muscimol-treated versus antagonist-treated cultures is shown in Figure $2 C$. Muscimol-treated cultures had significantly more LHRH neurons on the main tissue mass (0.1-0.4 $\mathrm{mm} ; p<0.001)$ and fewer LHRH cells in the periphery $(1.0 \mathrm{~mm}$, $p=0.004 ; 1.1 \mathrm{~mm}, p=0.01 ;>1.2 \mathrm{~mm}, p=0.02)$ than cultures treated with $\mathrm{GABA}_{\mathrm{A}}$ receptor antagonists $(p<0.05)$. The effect of $\mathrm{GABA}_{\mathrm{A}}$ receptor manipulation on $\mathrm{LHRH}$ neuronal migration is shown graphically in Figure $3 A$. The plotted values were obtained from the contingency table (see Materials and Methods) and represent the overall change observed in each zone, between treated cultures and those maintained in SFM alone. Points above the line indicate an increase in the number of LHRH neurons located at the given distance from the olfactory pit compared with the SFM group, whereas a point below the line indicates fewer LHRH neurons located at the given distance compared with the SFM group. In Figure $3 A$, one sees that a general increase in LHRH neurons at distant locations was observed in the cultures treated with antagonists, whereas a pronounced decrease in the number of LHRH neurons that were located distant from the olfactory pit was observed in muscimol-treated cultures. The latter effect was the most dramatic result. Whereas $48 \%$ of the SFM population was located beyond zone 4, on muscimol treatment, only $34 \%$ of the LHRH population migrated off of the main tissue mass, beyond zone 4 . In these same cultures, only $3 \%$ of the LHRH neuronal population migrated $>0.8 \mathrm{~mm}$ from the olfactory pits (compared with $11 \%$ of SFM population).

The $\mathrm{GABA}_{\mathrm{A}}$ receptor antagonists produced opposing (although less robust) effects on LHRH cell migration compared with the $\mathrm{GABA}_{\mathrm{A}}$ receptor agonist muscimol; a significant increase in the number of LHRH neurons located $>0.8 \mathrm{~mm}$ from the olfactory pit was observed (13\% compared with $3 \%$ of muscimol population and $11 \%$ of SFM population). To begin to determine whether any of the changes in location of LHRH neurons observed after pharmacological treatments were synaptically or trophically transduced, cultures were treated with TTX. After 7 div, explants were fixed and immunocytochemically processed. Treatment of cultures with TTX altered the location of LHRH cells compared with cultures maintained in SFM alone $\left(\chi^{2}=71.4 ; p<0.001 ; n=46\right)$. ANOVA analysis for each zone revealed an increase in LHRH cell numbers from 0.6 to $0.8 \mathrm{~mm}$ from the olfactory pit (Fig. $3 B$; zone $6, p=0.07$; zone $7, p=0.03$; zone $8, p=0.09)$.

\section{LHRH cell survival is independent of GABA}

Manipulation of GABAergic activity had no effect on LHRH cell survival as determined by total LHRH cell number. In SFM cultures, with a mean LHRH cell number of $182.9 \pm 13.8(n=$ 62 ), $\sim 23 \%$ of the total in vivo LHRH cell population was maintained. Similar LHRH cell survival occurred in each of the treatment groups [bicuculline, mean $=218.0 \pm 24.4(\sim 27 \%) ; n=$ 33; picrotoxin, mean $=198.2 \pm 26.1(\sim 25 \%) ; n=13$; muscimol, mean $=230.4 \pm 18.2(\sim 29 \%) ; n=27]$, in which no significant differences from SFM were observed (Fig. $4 ; F=1.37 ; p<0.26$ ). Thus, alterations in LHRH population distribution did not result from changes in LHRH cell survival.

\section{LHRH-peripherin axon interaction is maintained with alterations in GABAergic signaling}

The association of LHRH neurons with peripherin-positive axons was found to be independent of treatment. As shown by the examples in Figure 5, association of LHRH neurons with peripherin fibers was maintained in the presence of either drugs that inhibited (Fig. $5 A$ ) or activated (Fig. 5B) GABAergic receptors. This indicates that the observed changes in LHRH cell location were not attributable to a disruption of the neurophilic association of LHRH neurons with their molecular roadway.

\section{Olfactory axon outgrowth is independent of GABAergic signals}

Under all conditions, peripherin fiber outgrowth was robust, with the majority of fibers emerging preferentially from one side of the explant (Fig. 6A) and the fiber networks appearing comparable. In SFM cultures, quantitative assessment of peripherin outgrowth revealed a mean maximum network outgrowth of $1.18 \pm 0.04 \mathrm{~mm}$ $(n=76)$. As seen in Figure $6 B$, the extent of fiber outgrowth was similar among SFM cultures generated on different culture dates, and $>50 \%$ of all SFM cultures contained peripherin fibers that extended over $1 \mathrm{~mm}$ from the olfactory pit. Mean maximum network outgrowth in all GABA treatment groups was not significantly different from that obtained for the SFM group $\left[\chi^{2}=\right.$ 44.74; $p \geq 0.01$; picrotoxin, mean $=1.17 \pm 0.05 \mathrm{~mm}(n=34)$; bicuculline, mean $=1.3 \pm 0.05 \mathrm{~mm}(n=73)$; muscimol, mean $=$ $1.06 \pm 0.03 \mathrm{~mm}(n=70)]$. In addition, similar distributions of maximum fiber outgrowth were obtained, independent of treat- 


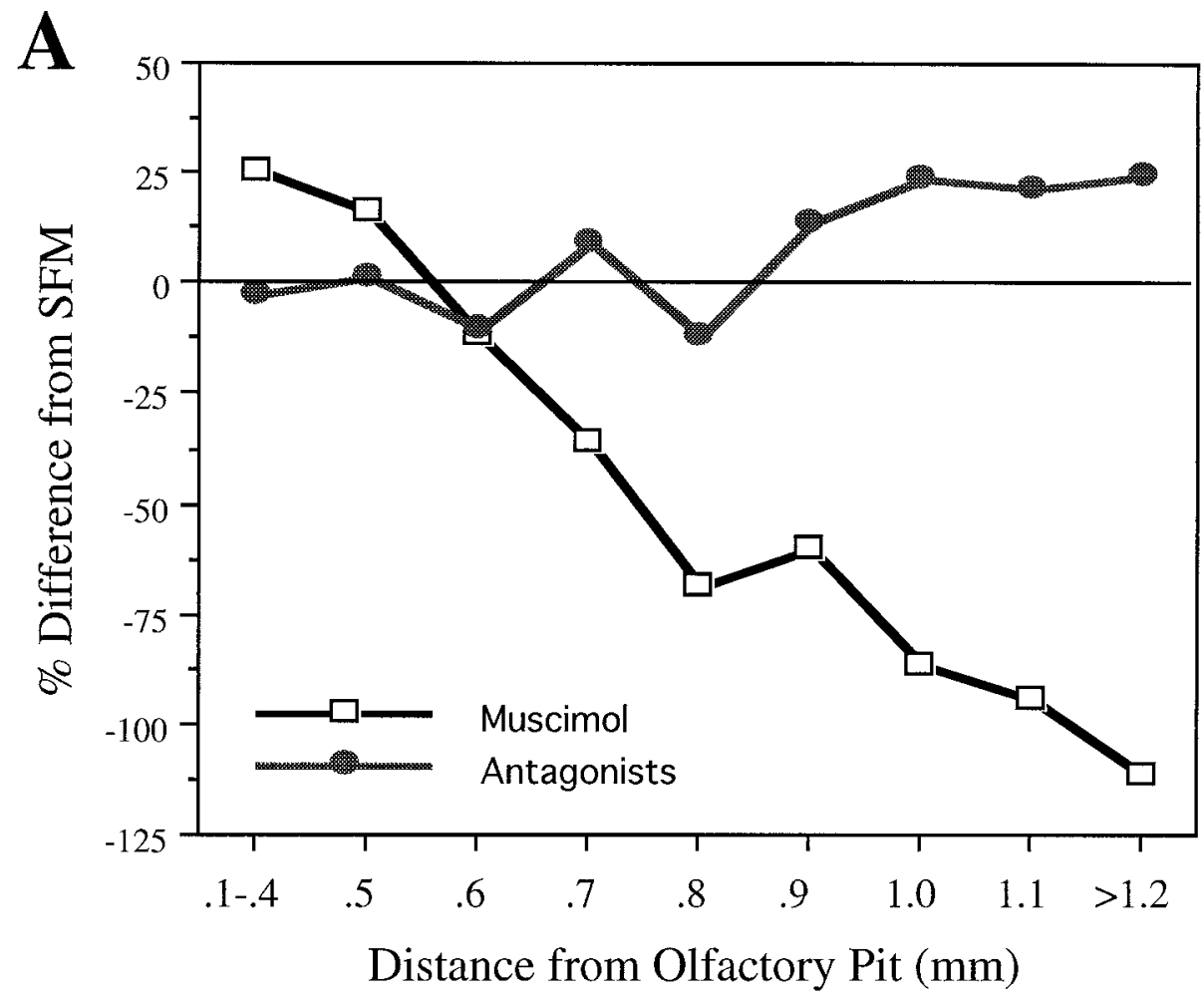

B

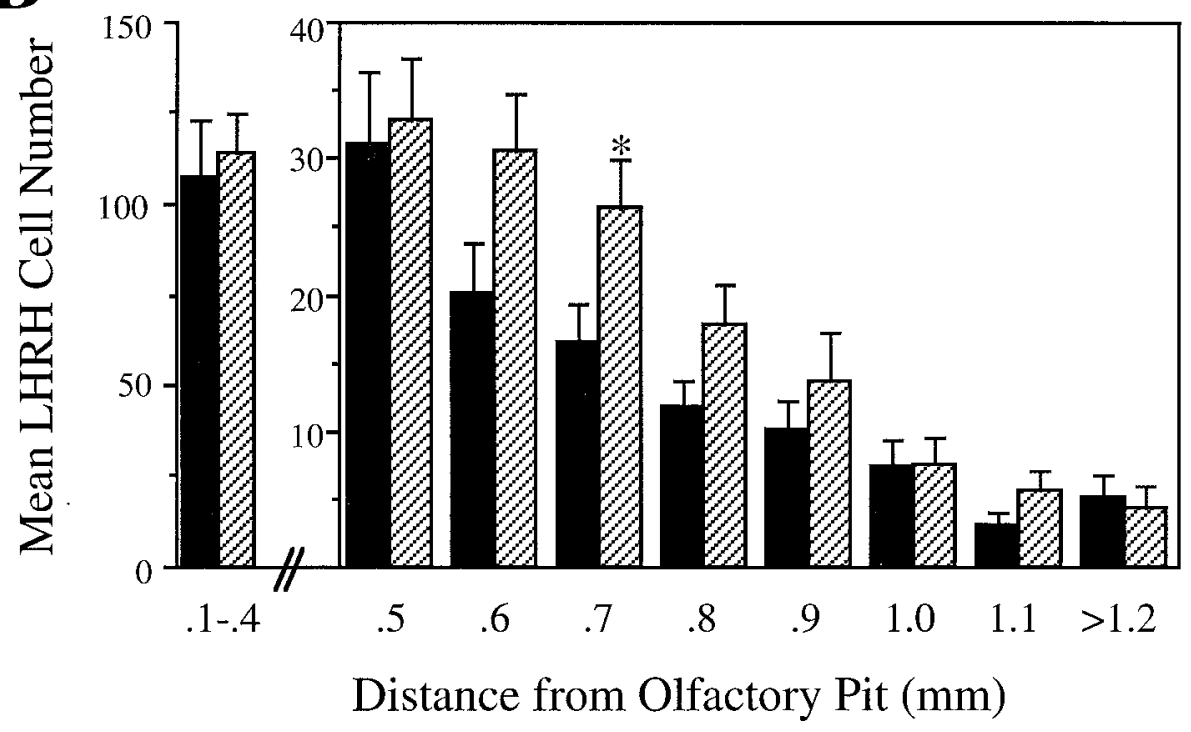

Figure 3. Location of LHRH neurons was dependent on treatment. LHRH cell migration was compared for SFM and experimental groups by constructing contingency tables and applying the $\chi^{2}$ test for independence. Analysis of LHRH neuronal location in the $\mathrm{GABA}_{\mathrm{A}}$ receptor treatment groups revealed a significant deviation from the expected population $\left(\chi^{2}=851.8 ; p<0.001\right)$. The percent difference from that observed in the SFM cultures is shown in $A$. Muscimol (culture, $n=47$; LHRH cell, $n=6327$ ) dramatically altered the location of LHRH neurons $\left(\chi^{2}=\right.$ 630.6; $p<0.001)$, decreasing the number of LHRH neurons located away from the olfactory pit. The $\mathrm{GABA}_{\mathrm{A}}$ receptor antagonists (combined, culture, $n=117$; LHRH cell, $n=$ $10,733)$ also altered $\left(\chi^{2}=27.5 ; p<0.001\right)$ the location of LHRH neurons, increasing the number of LHRH neurons that had moved away from the olfactory pit. Note the plotted values represent the overall change observed in each zone, between treated cultures and those maintained in SFM. Points above the line indicate increased numbers of LHRH neurons located within that zone, whereas points below the line indicate fewer LHRH neurons located at that distance from the olfactory pit. $B$, Inhibition of $\mathrm{Na}^{+}$-transduced electrical activity by TTX (culture, $n=46$; LHRH cell, $n=6306$ ) also altered the location of LHRH neurons $\left(\chi^{2}=71.4 ; p<\right.$ $0.001)$. Quantitation of mean LHRH cell number \pm SEM in each zone indicated that TTX treatment increased the number of LHRH neurons residing in zones $6-8$, suggesting that the observed effect on LHRH migration was via a spatially localized event (asterisk indicates value that is significantly different by ANOVA; $p=0.03)$. Solid bars, SFM cultures; hatched bars, TTX-treated cultures. ment (Fig. 6C). Mean maximum fiber outgrowth in cultures grown in TTX was also similar to that observed in SFM cultures (mean $=1.38 \pm 0.09 \mathrm{~mm} ; n=19)$. Thus, fiber network patterns, maximal fiber outgrowth, and directionality were maintained in all culture groups. Based on these parameters, the changes observed in the LHRH neuronal population do not appear to be a result of alterations in olfactory axon outgrowth.

\section{DISCUSSION}

The present work examines the effect of GABAergic activity, via $\mathrm{GABA}_{\mathrm{A}}$ receptors, on the development of LHRH neurons in embryonic nasal explants. We report dramatic alterations in
LHRH cell location, with no changes in LHRH cell survival, the neurophilic association of LHRH neurons with their molecular pathway, maximum olfactory axon outgrowth, or axon network patterns. This indicates that the observed changes were directly attributable to modulation of LHRH migration by GABA. We propose that, in vivo, the olfactory-derived GABAergic neurons provide a migratory "stop signal" for LHRH neurons, thereby regulating the timing of their entrance into the CNS.

\section{GABA as an embryonic stop signal}

It has become increasingly clear that modulation of neuronal activity during development may influence cell migration 


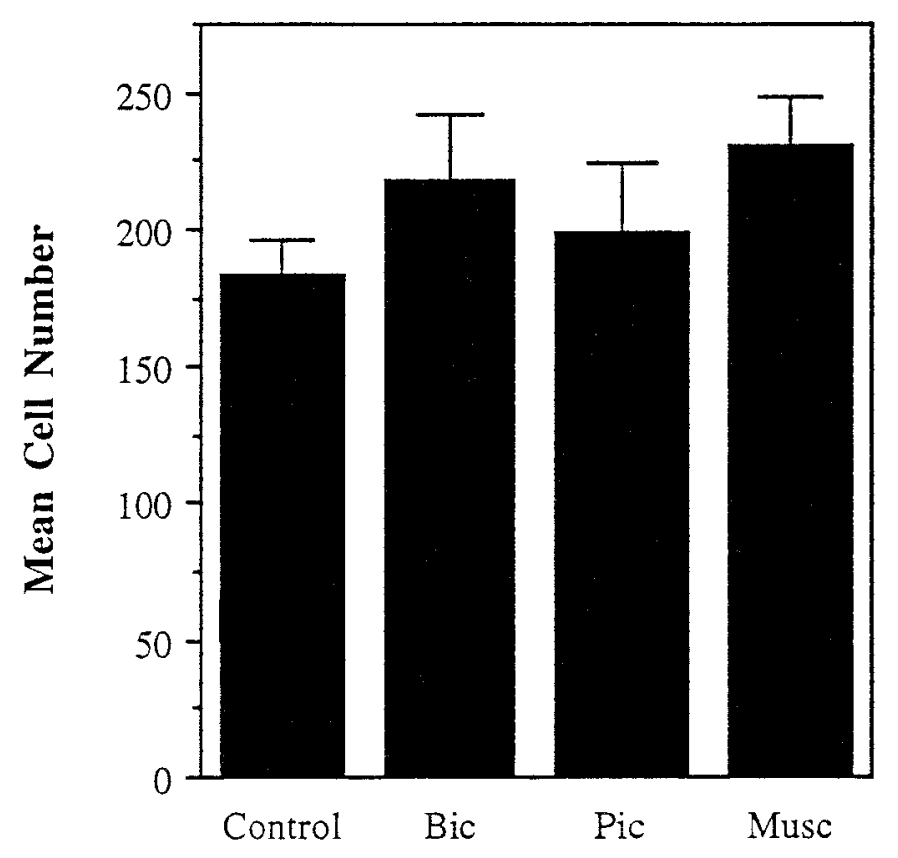

Treatment

Figure 4. Total number of LHRH neurons detected in olfactory explants was independent of pharmacological treatment. Immunopositive LHRH neurons were counted, and the data were plotted as mean cell numbers \pm SEM. No significant differences from SFM values were observed $(F=$ 1.37; $p<0.26$ ). SFM, $n=62$; bicuculline (Bic), $n=33$; picrotoxin (Pic), $n=13$; muscimol (Musc), $n=27$. Note that by E12.5, in vivo, $\sim 800$ LHRH neurons are present. Thus, in these olfactory explants $\sim 25 \%$ of the total population is maintained.

(Komuro and Rakic, 1992; Komuro and Rakic, 1993; Trenkner et al., 1996; Barker et al., 1997). Excitatory GABA responses, active before mature synaptogenesis, have been shown to alter migration of spinal cord and cerebellar neurons (Behar et al., 1994, 1996). GABAergic neurons are present in the olfactory pit and vomeronasal organ in embryonic mice at a time that correlates with the outgrowth of olfactory axons to the developing telencephalon and migration of LHRH neurons into the CNS (Tobet et al., 1996; Wray et al., 1996). In addition, by E12.5, robust staining of GABAergic-immunopositive axons (Wray et al., 1996) was observed at the site where LHRH neurons enter the developing brain. This GABAergic staining was localized to the nasal side of the cribiform plate, not crossing into the basal forebrain or entering the olfactory bulbs, as is seen for other olfactory axons (Wray et al., 1994). In light of these observations, it seemed likely that GABA could play a role in the development of the LHRH neuronal population.

The results of the present study clearly demonstrated that, in vitro, activation of $\mathrm{GABA}_{\mathrm{A}}$ receptors with the GABA mimetic muscimol inhibited embryonic LHRH cell migration. In contrast, bicuculline and picrotoxin caused a general shift in the location of LHRH neurons, increasing the distance migrated by the LHRH population. Interestingly, an increase in the number of LHRH cells within a specific migratory region was obtained on inhibition of electrical activity by TTX [which abolishes the transient inward current $\left(I_{\mathrm{NA}}\right)$ in LHRH neurons in nasal cultures (Kusano et al., 1995)]. This suggests that the observed effect on LHRH migration is not a trophic event but may result from a neuronal interaction that is spatially limited, such as is observed between GABAergic axons and LHRH neurons in vivo (Wray et al., 1996).

The onset of expression of functional $\mathrm{GABA}_{\mathrm{A}}$ receptors by LHRH neurons was unclear from previous studies (Kusano et al., 1995). In the present investigation, pharmacological perturbations were performed from 1 div onward. The results of these perturbations were not "all or none" but rather gradual shifts in the location of the LHRH neuronal population, consistent with LHRH neurons expressing $\mathrm{GABA}_{\mathrm{A}}$ receptors during their entire migratory phase. In previous work (Fueshko and Wray, 1994), LHRH neurons were detected in explants by 1 div and were localized to the olfactory pit. By 3 div, LHRH neurons had emigrated out of the olfactory pit to the surface of the culture, and between 3 and 5 div, LHRH cells were detected farther away from the olfactory pit, appearing in the periphery, on the nonneuronal carpet. Thus, there is a progression of LHRH neuron migration from the olfactory pit outward.

Clearly, cultures treated with muscimol showed a concomitant change in LHRH cell location, with an increase in the number of LHRH cells located on the main tissue mass and a decrease in the number of LHRH cells located distant from the olfactory pit (see Fig. 2C). The location of LHRH neurons in these cultures, mimicking only the early stages in the progression of LHRH neuron migration, provides strong evidence that LHRH neurons, as they begin migrating, express functional $\mathrm{GABA}_{\mathrm{A}}$ receptors. These data, taken together with the spatiotemporal targeting of GABAergic axons to the nasal-forebrain junction (Wray et al., 1996), support a developmental interaction between these two neuronal populations, previously thought to interact only after migration had ceased (Jennes et al., 1983; Leranth et al., 1985).

It should be noted that the effect of both $\mathrm{GABA}_{\mathrm{A}}$ receptor antagonists and TTX on LHRH neuronal movement were less robust than those observed after muscimol treatment. This may be attributed to the fact that the normal rate at which $\mathrm{LHRH}$ neurons move may already be maximum. However, unlike the antagonists, the stimulatory effect of TTX on LHRH neuronal movement was only observed between 0.6 and $0.8 \mathrm{~mm}$ from the olfactory pit. In vitro, GABAergic positive neurons were found adjacent to the main tissue mass $(0.5-0.6 \mathrm{~mm}$ from the olfactory pit), and immunopositive processes were observed slightly farther into the periphery of the explant $(0.9 \mathrm{~mm}$; see Fig. 4 , Wray et al., 1996). Thus, in olfactory explants, the location of GABAergic networks never extended as far as LHRH neurons. The presence of GABAergic elements in zones 5-9 may explain the spatially limited effects of TTX seen in our experiments. The action of the antagonists on LHRH neuronal migration at distances beyond $1.0 \mathrm{~mm}$ may be related to blockage of the receptors. In this case, compared with the TTX treatment, "leaking" GABA is unable to bind. Certainly, the exact nature of the GABAergic "input" to LHRH neurons in vitro requires further investigation. However, the effect of TTX observed in this study strengthens the argument for transient interactions between GABAergic and LHRH neurons prenatally. We propose that, in vivo, GABAergic input, present within a defined time window at the point of entrance to the CNS, acts to delay LHRH migration into the developing forebrain. In addition, we postulate that premature exposure of LHRH neurons to GABAergic activation may be prevented solely by the expression pattern of GABAergic axons, with LHRH neurons contacting GABAergic terminals only at the nasal-forebrain junction. 

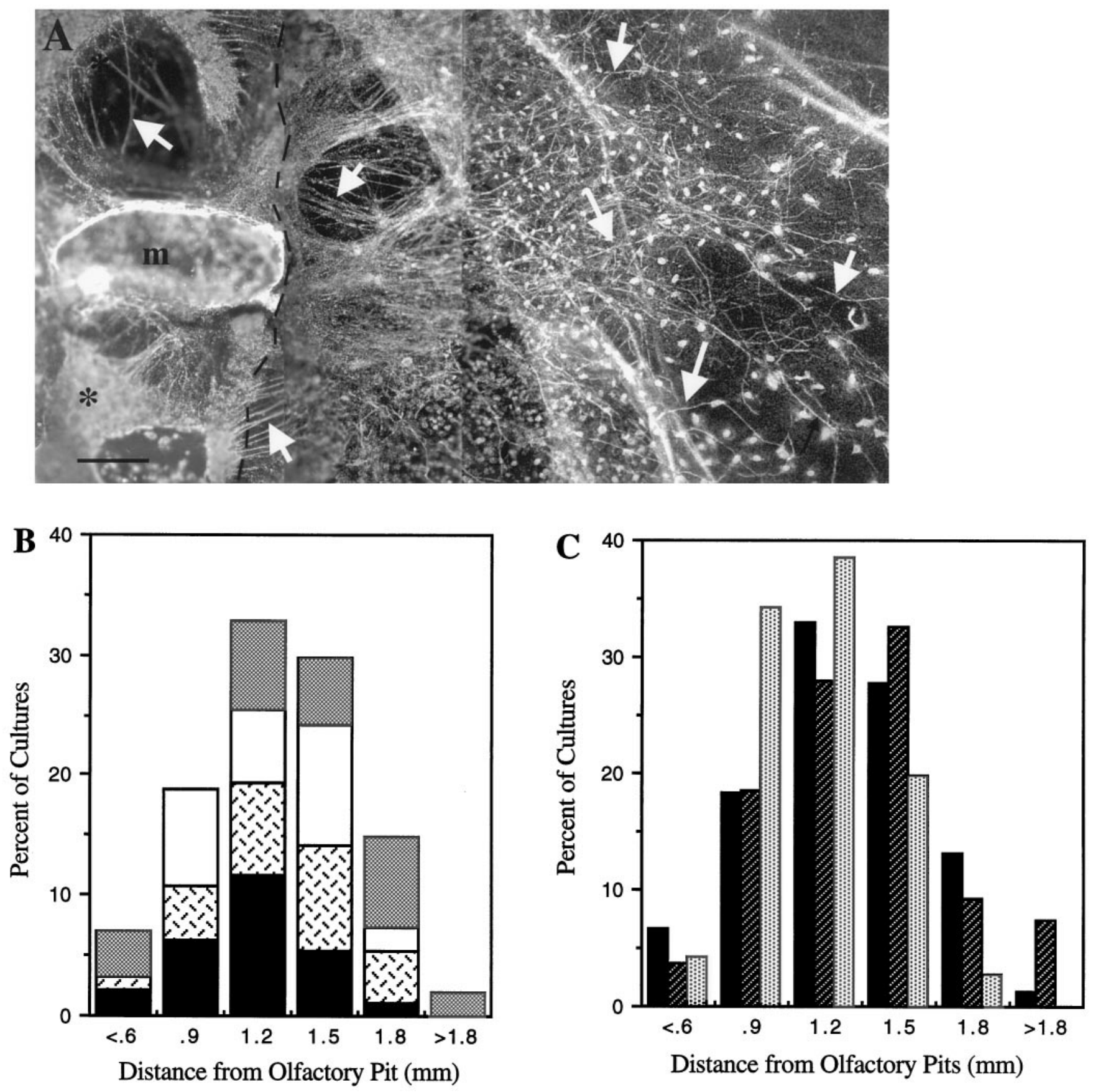

Figure 6. Olfactory axon outgrowth was unaffected by activation or inhibition of $\mathrm{GABA}_{\mathrm{A}}$ receptors. $A$, Dark-field photomicrograph of olfactory explant treated with $10^{-5} \mathrm{M}$ bicuculline then immunocytochemically stained for peripherin (arrows). Similar patterns of axon outgrowth were observed under all treatment conditions. The dashed line indicates the boundary between main tissue mass and carpet of non-neuronal cells; asterisk, olfactory pits; $m$, midline. Scale bar, $100 \mu \mathrm{m} . B$, Interassay variability in maximum fiber outgrowth. The number of cultures in SFM groups (generated on four separate culture dates) with fibers in a given segment was plotted as a percent of cultures analyzed $\left(n_{1}=24\right.$, solid bars; $n_{2}=13$, cross-hatched bars; $n_{3}=25$, white bars; $n_{4}=14$, stippled bars) versus the distance fibers were found from the olfactory pit. The total distance examined was divided into seven segments of $0.3 \mathrm{~mm}$. The maximum distance peripherin fibers extended from the olfactory pit was normally distributed, and most cultures showed maximum fibers $>1 \mathrm{~mm}$ in length. Note that the sum of the four individual percentages provides the distribution of the entire SFM culture group, which is depicted in $C$ (solid bars). $C$, Comparison of maximum fiber outgrowth for SFM and experimental groups. The number of cultures in each treatment group with fibers in a given segment was plotted as in B. SFM (solid bars), $n=76$; antagonist (hatched bars), $n=107$; muscimol (stippled bars), $n=70$.

\section{Why stop?}

The question raised by these studies is why LHRH neurons would require a pause before CNS entrance. A number of possibilities exist that require future examination. It is presently unknown whether LHRH neurons use the same pathway and/or molecules used through the nasal region as guides for migration into the forebrain. Thus, a delay at the nasal-forebrain junction may be necessary to allow (1) establishment of a new caudal pathway or (2) targeting of the pathway that LHRH neurons use in nasal regions to appropriate regions within the brain. Either 
scenario would ensure that the pathway necessary for LHRH neurons to attain their adult-like distribution is in place before their entrance into the forebrain.

Alternatively, a pause at the nasal-forebrain junction may be important for maturation of LHRH neurons. Early in development, LHRH neurons, such as neurons in the tectum (Lin et al., 1994), spinal cord (Wang et al., 1994), and hippocampus (Leinekugel et al., 1995), exhibit depolarizing responses to GABA (Kusano et al., 1995). High amounts of GABA are present in the developing brain at the time when LHRH neurons are migrating to their final destination (Lauder et al., 1986). If LHRH neurons responded to GABA in the brain, in a manner similar to their response in nasal regions, migration would cease prematurely. The anatomical continuum of LHRH cells would be disrupted, and reproductive function would be severely compromised (Radovick et al., 1991). In addition, it has been shown that depolarization can trigger secretion in LHRH neurons (Terasawa et al., 1993; Stojilkovic et al., 1994). If secretion of LHRH was to occur prematurely, in vivo, the result, again, would be severe reproductive dysfunction. Therefore, a delay, before CNS entry, may be necessary to allow LHRH neurons to modify their membrane response to GABAergic signals.

\section{The "depolarizing-to-hyperpolarizing" switch}

There are several means of modifying a membrane response to GABAergic signals. Modifications may be accomplished through (1) desensitization of $\mathrm{GABA}_{\mathrm{A}}$ receptors, moving the cells from a depolarized state to a quiescent state; and/or (2) maturation of the chloride pump, resulting in a developmental switch from depolarization to the hyperpolarizing response known to be present in mature LHRH neurons (Masotto and Negro-Vilar, 1987; Jarry et al., 1991). However, evidence is accumulating for a third explanation for the modulation of a pharmacological effect of GABA: phenotypic differentiation of neurons, leading to downregulation of $\mathrm{GABA}_{\mathrm{A}}$ receptors and/or changes in $\mathrm{GABA}_{\mathrm{A}}$ receptor subunit composition.

During development, $\mathrm{GABA}_{\mathrm{A}}$ receptor subunit transcripts exhibit regional and temporal expression profiles (Gambarana et al., 1991; Laurie et al., 1992; Elster et al., 1995; Hornung and Fritschy, 1996) directly related to their functional properties. It is increasingly clear that modulation of these expression patterns is accomplished through GABA stimulation of $\mathrm{GABA}_{\mathrm{A}}$ receptors (Baumgartner et al., 1994; Schousboe and Redburn, 1995; Poulter et al., 1997). The exact nature of this GABAergic signaling during development is unknown. However, activation of intracellular messenger systems in response to depolarization is likely. Of the classical second messengers, a rise in intracellular $\mathrm{Ca}^{2+}$ is a likely candidate (Miller, 1988). Thus, the transient expression of GABA, in a spatially defined location, may result in a change in intracellular $\mathrm{Ca}^{2+}$ and corresponding alterations in $\mathrm{GABA}_{\mathrm{A}}$ receptor subunit gene expression and, thus, receptor composition in LHRH neurons during a restricted period, just before entrance into the brain. A number of studies have indicated the presence of $\alpha 1, \beta 1$, and/or $\beta 3$ subunit mRNA in immortalized GT1 cells in vitro (Hales et al., 1992; el-Etr et al., 1993; Favit et al., 1993), and Petersen et al. (1993) have shown that the majority of adult LHRH neurons express $\beta 3$ subunit mRNA. Attempts to identify $\mathrm{GABA}_{\mathrm{A}}$ receptor subunits in embryonic LHRH neurons have not yet yielded conclusive results. However, such studies are clearly important for determining the molecular mechanisms underlying GABAergic signaling in migrating neurons.

In summary, we have used an in vitro embryonic explant system to characterize the migratory responses of LHRH neurons to alterations in GABAergic activity. The experiments provide evidence that migration of LHRH neurons in nasal regions is inhibited by pharmacological activation of $\mathrm{GABA}_{\mathrm{A}}$ receptors. The presence of GABA at the nasal-forebrain junction and the expression of functional $\mathrm{GABA}_{\mathrm{A}}$ receptors on embryonic $\mathrm{LHRH}$ neurons suggest that GABA, in part, regulates LHRH neuronal migration into the CNS.

\section{REFERENCES}

Agresti A (1984) Analysis of ordinal categorical data. New York, Wiley. Barker JL, Behar T, Li Y-X, Liu Q-Y, Ma W, Maric D, Maric I, Schaffner AE, Serafini R, Smith SV, Somogyi R, Vautrin JY, Wen X-L, Xian H (1997) GABAergic cells and signals in CNS development. Perspect Dev Neurobiol 4:1-16.

Baumgartner BJ, Harvey RJ, Darlison MG, Barnes Jr EM (1994) Developmental upregulation and agonist-dependent downregulation of $\mathrm{GABA}_{\mathrm{A}}$ receptor subunit mRNAs in chick cortical neurons. Brain Res Mol Brain Res 26:9-17.

Behar TN, Schaffner AE, Colton CA, Somogyi R, Olah Z, Lehel C, Barker JL (1994) GABA-induced chemokinesis and NGF-induced chemotaxis of embryonic spinal cord neurons. J Neurosci 14:29-38.

Behar TN, Li Y-X, Tran HT, Ma W, Dunlap V, Scott C, Barker JL (1996) GABA stimulates chemotaxis and chemokinesis of embryonic cortical neurons through calcium-dependent mechanisms. J Neurosci 16:1808-1818.

Catterall WA (1980) Neurotoxins action on sodium channels. Annu Rev Pharmacol Toxicol 20:15-43.

Cherubini E, Gaiarsa JL, Ben-Ari Y (1991) GABA: an excitatory transmitter in early postnatal life. Trends Neurosci 14:515-519.

el-Etr M, Akwa Y, Fiddes RJ, Robel P, Baulieu EE (1993) A progesterone metabolite stimulates the release of gonadotropin-releasing hormone from GT1-1 hypothalamic neurons via the gamma-aminobutyric acid type A receptor. Proc Natl Acad Sci USA 92:3769-3773.

Elster L, Hansen GH, Belhage B, Fritschy JM, Mohler H, Schousboe A (1995) Differential distribution of GABA $\mathrm{A}$ receptor subunits in soma and processes of cerebellar granule cells: effects of maturation and a GABA agonist. Int J Dev Neurosci 13:417-428.

Farbman AI (1994) Developmental biology of olfactory sensory neurons. Semin Cell Biol 5:3-10.

Favit A, Wetsel WC, Negro-Vilar A (1993) Differential expression of gamma-aminobutyric acid receptors in immortalized luteinizing hormone-releasing hormone neurons. Endocrinology 133:1983-1989.

Fueshko SM, Wray S (1994) LHRH cells migrate on peripherin fibers in embryonic olfactory explant cultures: an in vitro model for neurophilic neuronal migration. Dev Biol 166:331-348.

Gambarana C, Beattie CE, Rodriguez ZR, Siegel RE (1991) Regionspecific expression of messenger RNAs encoding $\mathrm{GABA}_{\mathrm{A}}$ receptor subunits in the developing rat brain. Neuroscience 45:423-432.

Hales TG, Kim H, Longoni B, Olsen RW, Tobin AJ (1992) Immortalized hypothalamic GT1-7 neurons express functional $\gamma$-aminobutyric acid type A receptors. Mol Pharmacol 42:197-202.

Halpern M (1987) The organization and function of the vomeronasal system. Annu Rev Neurosci 10:325-362.

Hille B (1984) Mechanisms of block. In: Ionic channels of excitable membranes. pp 298-302. Sunderland, MA: Sinauer.

Hornung JP, Fritschy JM (1996) Developmental profile of $\mathrm{GABA}_{\mathrm{A}^{-}}$ receptors in the marmoset monkey: expression of distinct subtypes in pre- and postnatal brain. J Comp Neurol 367:413-430.

Jarry H, Leonhardt S, Wuttke W (1991) Gamma-aminobutyric acid neurons in the preoptic/anterior hypothalamic area synchronize the phasic activity of the gonadotropin-releasing hormone pulse generator in ovariectomized rats. Neuroendocrinology 53:261-267.

Jennes L, Stumpf WE, Tappaz ML (1983) Anatomical relationships of dopaminergic and GABAergic systems with the GNRH-systems in the septo-hypothalamic area. Exp Brain Res 50:90-91.

Komuro H, Rakic P (1992) Selective role of N-type calcium channels in neuronal migration. Science 257:806-809.

Komuro H, Rakic P (1993) Modulation of neuronal migration by NMDA receptors. Science 260:95-97.

Kusano K, Fueshko SM, Gainer H, Wray S (1995) Electrical and synaptic properties of embryonic luteinizing hormone releasing hormone neurons in explant cultures. Proc Natl Acad Sci USA 92:3918-3922. 
Lauder JM (1987) Neurotransmitters as morphogenetic signals and trophic factors. In: Model systems of development and aging of the nervous system (Vernadakis A, ed), pp 219-237. Boston: Kluwer.

Lauder JM, Han VK, Henderson P, Verdoorn T, Towle AC (1986) Prenatal ontogeny of the GABAergic system in the rat brain: an immunocytochemical study. Neuroscience 19:465-493.

Laurie DJ, Wisden W, Seeburg PH (1992) The distribution of thirteen $\mathrm{GABA}_{\mathrm{A}}$ receptor subunit mRNAs in the rat brain. III. Embryonic and postnatal development. J Neurosci 12:4151-4172.

Leinekugel X, Tseeb V, Ben-Ari Y, Bregestovski P (1995) Synaptic $\mathrm{GABA}_{\mathrm{A}}$ activation induces $\mathrm{Ca}^{2+}$ rise in pyramidal cells and interneurons from rat neonatal hippocampal slices. J Physiol (Lond) 487:319-329.

Leranth D, MacLusky NJ, Sakamoto H, Shanabrough M, Nartolin F (1985) Glutamic acid decarboxylase-containing axons synapse on LHRH neurons in the rat medial preoptic area. Neuroendocrinology 40:536-539.

Lin M-H, Takahashi MP, Takahashi Y, Tsumoto T (1994) Intracellular calcium increase induced by GABA in visual cortex of fetal and neonatal rats and its disappearance with development. Neurosci Res 20:85-94.

Masotto C, Negro-Vilar A (1987) Activation of gamma-aminobutyric acid B-receptors abolishes naloxone-stimulated luteinizing hormone release. Endocrinology 121:2251-2255.

Meier E, Hansen GH, Schousboe A (1985) The trophic effect of GABA on cerebellar granule cells is mediated by GABA-receptors. Int J Dev Neurosci 3:401-407.

Meier E, Hertz L, Schousboe A (1991) Neurotransmitters as developmental signals. Neurochem Int 19:1-15.

Miller RJ (1988) Calcium signalling in neurons. Trends Neurosci 11:415-419.

Obata K, Oide M, Tanaka H (1978) Excitatory and inhibitory actions of GABA and glycine on embryonic chick spinal neurons in culture. Brain Res 144:179-184.

Parysek LM, Goldman RD (1988) Distribution of a novel 57 kDa intermediate filament (IF) protein in the nervous system. J Neurosci 8:555-563.

Petersen SL, McCrone S, Coy D, Adelman JP, Mahan LC (1993) $\mathrm{GABA}_{\mathrm{A}}$ receptor subunit mRNAs in cells of the preoptic are: colocalization with LHRH mRNA using dual-label in situ hybridization histochemistry. Endocr J 1:29-34.

Poulter MO, Ohannesian L, Larmet Y, Feltz P (1997) Evidence that $\mathrm{GABA}_{\mathrm{A}}$ receptor subunit mRNA expression during development is regulated by $\mathrm{GABA}_{\mathrm{A}}$ receptor stimulation. J Neurochem 68:631-639.

Quinton R, Hasan W, Grant W, Thrasivoulou C, Quiney RE, Besser GM, Bouloux PM (1997) Gonadotropin-releasing hormone immunoreactivity in the nasal epithelia of adults with Kallmann's syndrome and isolated hypogonadotropic hypogonadism and in the early midtrimester human fetus. J Clin Endocrinol Metab 82:309-314.

Radovick S, Wray S, Lee E, Nicols DK, Nakayama Y, Weintraub BD, Westphal H, Cutler Jr GB, Wondisford FE (1991) Migratory arrest of gonadotropin-releasing hormone neurons in transgenic mice. Proc Natl Acad Sci USA 88:3402-3406.
Rugarli EI, Lutz B, Kuratani SC, Wawersik S, Borsani G, Ballabio A, Eichele G (1993) Expression pattern of the Kallmann syndrome gene in the olfactory system suggests a role in neuronal targeting. Nat Genet $4: 19-26$.

Schousboe A, Redburn DA (1995) Modulatory actions of gamma aminobutyric acid (GABA) on GABA type A receptor subunit expression and function. J Neurosci Res 41:1-7.

Schwanzel-Fukuda M, Pfaff DW (1989) Origin of luteinizing hormonereleasing hormone neurons. Nature 338:161-164.

Stojilkovic SS, Krsmanovic LZ, Spergel DJ, Tomic M, Catt K (1994) Calcium signaling and episodic secretory responses of $\mathrm{GnRH}$ neurons. In: Methods in neuroscience (Levine J, ed), pp 68-84. San Diego: Academic.

Terasawa E, Quanbeck CD, Schulz CA, Burich AJ, Luchansky LL, Claude P (1993) A primary cell culture system of luteinizing hormone releasing hormone (LHRH) neurons derived from embryonic olfactory placode in the Rhesus monkey. Endocrinology 133:2379-2390.

Tobet SA, Chickering TW, King JC, Stopa EG, Kim K, Kuo-Leblank V, Schwarting GA (1996) Expression of gamma-aminobutyric acid and gonadotropin-releasing hormone during neuronal migration through the olfactory system. Endocrinology 137:5415-5420.

Trenkner E, el Idrissi A, Harris C (1996) Balanced interaction of growth factors and taurine regulate energy metabolism, neuronal survival, and function of cultured mouse cerebellar cells under depolarizing conditions. Adv Exp Med Biol 403:507-517.

Wang J, Reschling DB, Kyrozis A, MacDermott AB (1994) Developmental loss of GABA- and glycine-induced depolarization and $\mathrm{Ca}^{2+}$ transients in embryonic rat dorsal horn neurons in culture. Eur J Neurosci 6:1275-1280.

Wray S, Gahwiler BH, Gainer H (1988) Slice cultures of LHRH neurons in the presence and absence of brainstem and pituitary. Peptides 9:1151-1175.

Wray S, Grant P, Gainer H (1989a) Evidence that cells expressing luteinizing hormone-releasing hormone mRNA in the mouse are derived from progenitor cells in the olfactory placode. Proc Natl Acad Sci USA 86:8132-8136.

Wray S, Nieburgs A, Elkabes S (1989b) Spatiotemporal cell expression of luteinizing hormone-releasing hormone in the prenatal mouse: evidence for an embryonic origin in the olfactory placode. Dev Brain Res 46:309-318

Wray S, Kusano K, Gainer H (1991) Maintenance of LHRH and oxytocin neurons in slice explants cultured in serum-free media: effects of tetrodotoxin on gene expression. Neuroendocrinology 54:327-339.

Wray S, Key S, Qualls R, Fueshko SM (1994) A subset of peripherin positive olfactory axons delineates the luteinizing hormone releasing hormone neuronal migratory pathway in developing mouse. Dev Biol 166:349-354.

Wray S, Fueshko SM, Kusano K, Gainer H (1996) GABAergic neurons in the embryonic olfactory pit/vomeronasal organ: maintenance of functional GABAergic synapses in olfactory explants. Dev Biol 180: 631-645. 